\title{
Legal Certainty for the Provision of Employee Services as the Intent of Protection of Labor Rights based on Labor Rights and Its Implementation in PT. Semen Padang
}

\author{
Robie Brilliando Sukanda; Khairani; Yussy Adelina Mannas \\ Andalas University, Padang, West Sumatera, Indonesia \\ http://dx.doi.org/10.18415/ijmmu.v7i6.1783
}

\begin{abstract}
Outsourcing was born as a side effect of the implementation of business process reengineering (BPR). Another problem that arises from outsourcing practices is the elimination of labor rights by employers. Based on the Constitutional Court Decision (MK Decision No. 27 / PUU-IX / 2011), the Court emphasized that Outsourcing is a reasonable business policy of a company in the context of business efficiency. However, workers who carry out work in an outsourcing company may not lose their rights which are protected by the constitution. Following up on the Constitutional Court Decision, the Ministry of Manpower and Transmigration has issued Circular Letter Number B.31 / PHIJSK / I / 2012 concerning Implementation of the Constitutional Court Decision Number 27 / PUU-IX / 2011 dated January 17, 2012. Based on this, there are 3 (three ) The legal issues that the author will examine are: (1) How is the suitability of the implementation of the provision of worker services at PT. Semen Padang with the applicable law; (2) How to fulfill workers' rights in the implementation of Worker Service Provision at PT. Semen Padang; and (3) What are the negative and positive consequences of the implementation of the Provision of Worker Services on workers' rights at PT. Semen Padang. This exploratory research reveals how the application of legal norms from Law Number 13 of 2003 concerning Manpower and Regulation of the Minister of Manpower and Transmigration Number 19 of 2012 concerning Requirements for Submission of Part of Work Implementation to other companies at PT. Semen Padang. From the results of the study concluded that: (1) Implementation of the provision of employee services at PT. Semen Padang has not complied with the applicable law. On the one hand, PT. Semen Padang has implemented the provisions of Article 66 paragraph (3) of the Manpower Act. PT. Semen Padang has set one of the most basic requirements, namely the vendor must have an Operational Permit (SIO) for Manpower Providers issued by the Department of Manpower (Disnaker) of West Sumatra Province. PT Semen Padang has also complied with the provisions of Article 17 Paragraph (3) of the Regulation of the Minister of Manpower and Transmigration No. 19 of 2012. On the other hand, PT. Semen Padang still uses worker service providers for jobs that are not regulated in Article 17 of the 2012 Minister of Manpower Regulation or even doing work that should be done by employees of PT Semen Padang itself; (2) The fulfillment of the rights of outsourcing workers at PT Semen Padang has been carried out quite well, where this can be proven by PT Semen Padang providing legal protection to Outsourcing Workers through the Decree of the Board of Directors of PT.Semen Padang No. 0000143 / HK.00.02 / SKD / 50003853/3000 / 12.2017 dated 21 December 2017 concerning Changes in the Value Structure of PT Semen Padang's Outsourcing Labor Contract, and (3) Implementation of Provision of Worker Services at PT. Semen Padang has negative consequences and positive consequences. The
\end{abstract}


negative consequence is the high level of jealousy of the outsourcing workers towards organic workers, both in terms of the type of work performed, the uniforms worn, and differences in workers' rights. One of the positive consequences of employing outsourcing workers, labor costs can be reduced in one way through the provision of worker services.

Keywords: Legal Certainty; Employment; Legal Protection

\section{Introduction}

Indonesia is one of the countries in the world that considers employment and labor is a human rights issue for every citizen. It can be seen that employment and labor issues (hereinafter referred to as employment) are guaranteed in the 1945 Constitution of the Republic of Indonesia (hereinafter quoted as the UUD) in Article 27 Paragraph (2) of the Constitution which states that "the rights of every citizen the country to get a job and a decent living for humanity ". Furthermore, Article 28 D Paragraph (2) guarantees that the right of citizens to work must be interpreted as the right "the right to work and to receive fair and proper compensation and treatment in an employment relationship."

Article 27 Paragraph (2) and Article 28 D Paragraph (2) of the 1945 Constitution as described above are basic norms for the Government of the Republic of Indonesia (RI Government) in carrying out economic development, especially those related to manpower. Thus, the goal of manpower development is to provide protection to every citizen in order to achieve prosperity and justice. ${ }^{1}$ On that basis, every citizen must be guaranteed the right not to be treated arbitrarily and unfairly. ${ }^{2}$ Manpower arrangements by the Government of the Republic of Indonesia must not side with employers by oppressing workers. This could give birth to Capitalism and Neoliberalism which created a situation where investors were robbed of workers' rights. ${ }^{3}$ This can no longer happen in Indonesia because the Indonesian government has implemented the "Pancakrida" labor law, which stipulates that :

1. Freeing Indonesian people from slavery and slavery.

2. Liberation of Indonesian people from corpse or forced labor.

3. Exemption of Indonesian laborers / workers from potential sanctions.

4. Liberation of Indonesian workers / workers from the fear of losing their jobs.

5. Provide a balanced position between laborers / workers and entrepreneurs. ${ }^{4}$

In the framework of implementing the Pancakrida above, protection of labor rights has been carried out by the Government of Indonesia since the beginning of independence by issuing regulations, including the following :

1. Law Number 22 Year 1957 concerning the Settlement of Labor Disputes, ${ }^{5}$

2. Law No. 12 of 1964 concerning Termination of Employment in Private Companies; ${ }^{6}$

3. Law No. 21 of 2000 concerning Workers Union; ${ }^{7}$

\footnotetext{
${ }^{1}$ Khairani, 2016, Legal Certainty of the Rights of Outsourcing Workers in terms of the Concept of a Work Relationship between Workers and Employers, PT. Raja Grafindo Persada, Jakarta, p. 2.

${ }^{2}$ FX Djumiadji, 1987, Contracting Agreement, Publisher Bina Aksara, Jakarta, p. 1.

${ }^{3}$ Mukhammad Riza Anugra Vidi and M. Arif Affandi, 2015, "Labor Union Resistance Movement for Outsourcing Systems and Wage Systems at PT JAPFA Comfeed Sidoardjo," Paradigma, Volume 03 Number 1.

${ }^{4}$ Lalu Husni, 2010, Indonesian Manpower Law, Revised Edition, Rajawali Pers, Jakarta, p. 4. Read also: Muhamad Azhar, 2015, Manpower Law Textbook, Indonesian Police Academy, Semarang, p. 20.

5 "Law No. 22 of 1957 concerning Settlement of Hunting Disputes, "State Gazette, No. 22 of 1957.

6 "Law No. 12 Years concerning Termination of Employment in Private Companies, "State Gazette No. 12 of 1964, Supplement to the State Gazette No. 2686.
} 
4. Law No. 13 of 2003 concerning Manpower;

5. Minister of Manpower and Transmigration Regulation No. 19 of 2012 concerning the Conditions for Submitting Part of the Work Implementation to Another Company;

6. Presidential Regulation No. 20 of 2018 concerning the Use of Foreign Workers; and

7. Minister of Manpower Regulation No. 10 of 2018 concerning Procedures for the Use of Foreign Workers.

With the enactment of the aforementioned Regulations, the position of the workforce is getting stronger and causes many companies to feel overwhelmed with labor matters. The demands for competition in the era of globalization in the business world are very tight at this time. On that basis, many companies try to improve their business performance through effective and efficient organizational management, and tighten production costs. ${ }^{8}$ One of the efforts made is by employing a minimum number of workers to be able to provide the maximum contribution according to the company's production targets. For this reason, the company seeks to focus on handling work that is the core business, while supporting work is left to other parties. Submission of work to other parties is known as outsourcing. ${ }^{9}$

The term Outsourcing is not found directly in the provisions of Law Number 13 Year 2003 concerning Manpower (hereinafter abbreviated as Manpower Law). ${ }^{10}$ Article 64 of the Manpower Act only states that "a company can hand over part of the work implementation to another company through a written contract of work or the provision of worker / labor services made in writing". The provisions of Article 64 of the Manpower Act mean that a company can hand over part of the work implementation to another company through a written contract of work or the provision of worker services. In the manpower sector, outsourcing is defined as the use of labor to produce or carry out a job by a company. , through labor providers / recruiters. ${ }^{11}$ From this understanding, it is concluded that there are 3 parties involved in the outsourcing agreement, namely: the company providing worker services, the company providing the job, and the workers themselves. A company that provides worker services is a company that accepts workers which then transfers the workers to the company that provides the job to work for the company according to a written agreement. Then the term Outsourcing was born, (in this case it means using human resources from parties outside the company). ${ }^{12}$

Workers from labor service providers may not be used by the employing company to carry out activities that are directly related to the production process except for supporting services or activities that are not directly related to the production process as regulated in Article 66 paragraph (1) of the Manpower Act. Based on the provisions of Article 66 paragraph (2) of this Manpower Act, the requirements for labor service providers are as follows :

a. There is a working relationship between workers and companies providing labor services;

b. There is a work agreement between the worker and the labor service provider company;

c. The protection of welfare and all disputes is the responsibility of the labor service provider; and

\footnotetext{
7 "Law No. 21 of 2000 concerning Trade Unions / Labor Unions, "State Gazette No. 131 of 2000, Supplement to the State Gazette No. 3989.

${ }^{8}$ Abd. Munir, 2013, "Structural Victimization of Workers through the Outsourcing System (Case Study: Outsourcing Workers of PT. (X) employed at PT. (Y) in Serang Regency)," Indonesian Journal of Criminology, Volume 9 No. 1, p. 32.

${ }^{9}$ Khairani, op. cit., p. 3; See also Gotra Lidya Puspita and Mochamad Affandi, "Analysis of the Distribution of Workers by Outsourcing Companies in Airlines Companies (Case Study at PT. Mandala Airlines," JIEP, Vol. 15 No. 2 November 2015, p. 58; See also Ariswan, Regarding Outsourcing Personnel, http://malangnet.wordpress.com, (accessed on 26 January 2015).

10 "Law No. 13 of 2003 concerning Manpower, "State Gazette No. 39 of 2003, Supplement to the State Gazette No. 4279.

${ }^{11}$ Lalu Husni, op. cit., p. 187.

12 Adrian Sutedi, 2011, Labor Law, Sinar Grafika, Jakarta, p. 217.
} 
d. There is a written agreement between the employing company and the labor service provider which must contain the provisions contained in the Manpower Act.

Employment service providers must be legal entities and have a license from the relevant agency in the field of manpower. This is in accordance with Article 66 paragraph (3) of the Manpower Act. Outsourcing arrangements in Articles 64 and 66 of the Manpower Act are still general in nature where Law Number 13 of 2003 concerning Manpower should be able to become a legal protector for outsourcing workers. However, the Law has a vacuum of norms, because it does not have specific rules for outsourcing workers. If the parties related to outsourcing (company or workforce) commit a violation, of course they cannot be held accountable according to their actions, because the existing rules or sanctions are less binding, so that it can harm one party. Outsourcing workers are more often affected by the impact, because between outsourcing workers and employing companies there are no binding rules in the form of legislation or work agreements.

To fill the legal void contained in Law Number 13 of 2003, the Minister of Manpower and Transmigration issued a Regulation of the Minister of Manpower and Transmigration Number 19 of 2012 concerning Conditions for Submitting Part of Work Implementation to Other Companies. Based on the provisions of Article 17 Paragraph (2) of the Regulation of the Minister of Manpower and Transmigration Number 19 of 2012, jobs that can be submitted to labor service providers are support services that are not directly related to the production process. Types of supporting service activities are described in Article 17 Paragraph (3) of the Regulation of the Minister of Manpower and Transmigration Number 19 of 2012, namely, among others :

a. Cleaning service businesses (cleaning service);

b. The business of providing food for workers / laborers (catering);

c. Security personnel business (security / security unit);

d. Supporting service businesses in mining and petroleum; and

e. The business of providing transportation for workers / laborers.

The requirements for labor service providers based on Article 24 of the Minister of Manpower and Transmigration Regulation Number 19 of 2012 are as follows:

a. Legalized as a PT;

b. Has a company registration mark;

c. Have a business license;

d. Have proof of compulsory employment report;

e. Have an operational license;

f. Has a permanent office and address;

g. Have a company NPWP.

Referring to the provisions of Article 1 of the Regulation of the Minister of Manpower and Transmigration Number 19 of 2012, the employing company is a company that submits part of the implementation of its work to the contracting recipient company or the worker / labor service provider company. Meanwhile, a company that provides employment services is a company in the form of a limited liability company (PT) which meets the requirements to carry out company support services from the company providing the job. But in reality, there are several companies that accept jobs that are not legal entities but in the form of CVs, cooperatives, and / or other business entities so that there are several legal problems both for the employing company and for the workers they employ. 
The implementation of outsourcing can be assessed from two conflicting perspectives between the employing company and the workers. On the one hand, Outsourcing is very profitable for the employing company because it can run its business without thinking about complicated matters concerning labor such as recruitment, dismissal and labor coaching. On the other hand, outsourcing for workers is very detrimental because the industrial relations that occur are very unequal, which results in low-paying and high-paying work groups that are easily replaced at any time. Outsourcing is used as a cost-saving strategy and at the same time is used as a way for employing companies to avoid legal obligations regulated in labor law, for example the obligation to pay severance pay in the event of termination of employment. In addition, outsourcing can be used by employing companies to avoid responsibility to third parties or consumers due to neglect of work. ${ }^{13}$

Based on the above matters, Outsourcing is getting resistance from many workers. One of them is the resistance movement against PT Japfa Comfeed in Sidoarjo. This resistance is a manifestation of the efforts of the SPAI-FSPMI (Miscellaneous Industry Workers Union - Indonesian Metal Workers Union Federation) in protecting against violations committed by employers against workers. One of the main concerns is the deprivation of workers' rights related to work status that should be a permanent employee to be transferred to Outsourcing and the application of wages in companies is not in accordance with the Regent's Decree regarding Regency / City Minimum Wage (UMK) this is the basis of resistance SPAI. The resistance movement undertaken by SPAI against PT Japfa Comfeed is determined by its perspective on the relationship between employers and laborers. The perspective of the SPAI-FSPMI is very different from the point of view of PT Japfa Comfeed. This different point of view creates a dynamic in setting policies in the company. This dynamic projects two conflicting views. This projection is contained in the resistance movement carried out by SPAI in suing PT Japfa Comfeed. The resistance effort from SPAI against PT. Japfa Comfeed in Sidoarjo is a manifestation of the contradiction between the two views. ${ }^{14}$

Outsourcing is the delegation of daily operations and management of a business process to outside parties (outsourcing service providers). Through delegation, management is no longer carried out by the company, but is delegated to the outsourcing service company. In other words, outsourcing or outsourcing is the process of transferring responsibility for labor from other companies outside the parent company. ${ }^{15}$ Outsourcing in the labor regulations only covers labor in supporting processes (non-core business units) or practically all lines of work can be transferred as outsourcing units. In simple terms, outsourcing can be illustrated by the existence of a service provider company that recruits prospective workers to be placed in a worker service company. ${ }^{16}$ Employment relationship with employee service provision agreement :

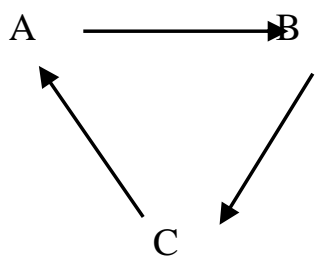

$$
\begin{aligned}
& A=\text { Employer } \\
& B=\text { Employee } \\
& C=\text { Workers }
\end{aligned}
$$

Note : A the employer / service user needs workers to carry out the work, B provides workers. A and $\mathrm{B}$ enter into a cooperation agreement. $\mathrm{C}$ is employed at $\mathrm{A}$. $\mathrm{C}$ works for $\mathrm{A}$ as a service user. This

\footnotetext{
${ }^{13}$ Khairani, op. cit., p. 5-6.

${ }^{14}$ Mukhammad Riza Anugra Vidi dan M. Arif Affandi, op. cit., p. 5.

${ }^{15}$ Sehat Damanik, 2006, Outsourcing \& Work Agreement According to Law Number 13 Year 2003 concerning Manpower, DSS Publishing, Jakarta, p. 10; See also Evi Rosmanasari, 2008, Implementation of Legal Protection for Outsourcing Workers of PT. Indah Karya Nuansa Indonesia (PT. INKANINDO) at PT. Pertamina (Persero) UP-VI Balongan, Thesis, Diponegoro University, p. 28.

${ }^{16}$ Khairani, 2014, "Position of Outsourcing Post-Constitutional Court Decision Number 27 / PUU-IX / 2011", Journal of the Constitution Volume 11.
} 
worker service provider employment agreement is more appropriately called a worker placement agreement. ${ }^{17}$

For Indonesia, the implementation of the Outsourcing system in the manpower system provides 3 (three) very profitable benefits. This advantage occurs because the Outsourcing system creates labor and labor market flexibility. The first benefit, the labor flexibility policy improves the investment climate. This means that the flexibility of the workforce is an incentive for investors to invest in Indonesia. Second, outsourcing stimulates the growth of employment opportunities (work opportunity). The last is that Outsourcing can reduce the level of poverty (poverty) because Outsourcing opens up greater job opportunities. $^{18}$

Outsourcing was born as a side effect of the implementation of business process reengineering (BPR), namely changes made by a company in its management process, not just making improvements. BPR is a new approach to management that aims to improve performance, which is very different from the old approach, namely the Continuous Improvement Process (CIP). BPR is carried out to respond to global economic developments and rapid technological developments, thus developing global and tight competition. ${ }^{19}$

Another problem that arises from outsourcing practices is the elimination of labor rights by employers. Based on the Constitutional Court Decision (MK Decision No. 27 / PUU-IX / 2011), the Court emphasized that Outsourcing is a reasonable business policy of a company in the context of business efficiency. However, workers who carry out work in an outsourcing company may not lose their rights which are protected by the constitution. So that workers are not exploited, the Court offers two models of Outsourcing. First, by requiring that the work agreement between the worker and the company carrying out the outsourcing work is not in the form of a fixed-time work agreement ("PKWT"), but is in the form of an indefinite work agreement ("PKWTT"). Second, applying the principle of transferring protective measures for workers who work for companies that carry out outsourcing work. Therefore, through the first model, the working relationship between the worker and the outsourcing company is considered constitutional as long as it is carried out based on a written PKWTT. Meanwhile, in the second model, in the case of a work relationship between workers and an outsourcing company based on nonpermanent contracts, workers must still get protection for their rights by applying the principle of transfer of protective measures. Following up on the Constitutional Court Decision, the Ministry of Manpower and Transmigration has issued Circular Letter Number B.31 / PHIJSK / I / 2012 concerning the Implementation of the Constitutional Court Decision Number 27 / PUU-IX / 2011 dated January 17, 2012 to regulate more precisely the mechanisms that it's already running.

The determination of PT. Semen Padang as a Research Location is because PT. Semen Padang is the largest company in Sumatra. PT Semen Padang has 1,297 organic employees and 2,959 outsourcing workers. This company uses the largest outsourcing workforce, namely $2 / 3$ of its employees are Outsourcing employees. Meanwhile, the number of companies providing labor services at PT Semen Padang is 73 companies. PT Semen Padang will become a role model or benchmark for the implementation of outsourcing. The large number of employees and outsourcing companies does not rule out the possibility of causing several problems related to the implementation of laws and regulations related to manpower, both in operational and policy terms. One example is the existence of employees from one of the labor providers in a certain unit who do administrative work where administrative work is not included in the criteria based on Article 17 (3) of the Regulation of the Minister of Manpower and

\footnotetext{
${ }^{17}$ Khairani, 2015, "Realizing Legal Protection for Outsourcing Workers through Synchronization of Employment Arrangements, Journal of Dynamics Faculty of Law, Jendral Sudirman University Volume 15 No.3.

18 Khairani, op. cit., p. 5.

19 Evi Rosmanasari, loc.cit; Read also Sonhaji, 2007, "Legal Aspects of Employment Relationships through Outsourcing Mechanisms Based on Law no. 13 of 2003 concerning Manpower, "Magazine of Legal Issues, Vol. 36 No. 2., p. 112.
} 
Transmigration Number 19 of 2012, and those related to worker welfare. There is one problem, namely the process of paying salaries by service providers to workers who are late while rights like this are guaranteed by Law Number 13 of 2003 concerning Manpower.

There are several previous studies which have similarities with this research. But these studies have different objects so this can prove the authenticity of this research. The previous studies referred to are as follows:

1. Evi Rosmanasari's thesis entitled Implementation of Legal Protection Against the Outsourcing Workers of PT. Indah Karya Nuansa Indonesia (PT. INKANINDO) at PT. Pertamina (Persero) UP-VI Balongan, in the Postgraduate Program of Law, Diponegoro University, Semarang University Graduate Program in 2008. Evi Rosmanasari's thesis has three problem formulations, namely: (a) How is the Implementation of Legal Protection Against PT. INKANINDO who worked at PT. PERTAMINA (Persero) UP-VI BALONGAN? (b) What obstacles faced by PT. INKANINDO as an Outsourcing Manpower Provider in providing protection for its workforce? ; and (c) What measures are taken to overcome obstacles. in providing that protection.

2. Muhammad Ilham Mirza's Thesis entitled Submission of Part of Work Implementation to Other Companies (Outsourcing) Through an Agreement to Provide Worker / Labor Services at PT Semen Padang in the Masters Program in Law, Postgraduate Program, Andalas University, Padang in 2017. This thesis concentrates on research on (1) what is the process of handing over part of the implementation of work to other companies (Outsourcing) through an agreement to provide worker / labor services at PT Semen Padang? (2) Why does PT Semen Padang submit supporting work through the pattern of providing worker / labor services apart from the 5 types of supporting work which is stipulated in statutory regulations ?, and (3) why does PT Semen Padang enter into an agreement for the provision of worker / labor services with a legal entity in the form of a cooperative.

Based on what is stated above, this study aims to identify and disclose 3 (three) legal issues as follows:

1. How is the suitability of the implementation of the provision of worker services at PT. Semen Padang with the applicable law ?

2. How to fulfill workers' rights in the implementation of Worker Service Provision at PT. Semen Padang ?

3. What are the negative and positive consequences of the implementation of the Provision of Worker Services on workers' rights at PT. Semen Padang?

To discuss and analyze the legal data collected in this study, there are 3 (three) kinds of theories used. The three theories referred to are the theory of utilitarianism, the theory of legal certainty and the theory of legal protection.

\section{Research Methods}

This research is a research that examines how the application of legal norms from Law Number 13 of 2003 concerning Manpower and Regulation of the Minister of Manpower and Transmigration Number 19 of 2012 concerning the Requirements for Submission of Part of Work Implementation to Other Companies at PT. Semen Padang is connected because the study of this research is the norms in reality (law in action), ${ }^{20}$ then this research qualifies as empirical legal research (juridical empirical). This

\footnotetext{
${ }^{20}$ Soetandyo Wignyosubroto, 2002, “Law, Paradigm, Methods and the Dynamics of the Problem”, Elsham, Jakarta, p. 147.
} 
research reveals how the application of legal norms from Law Number 13 of 2003 concerning Manpower and Regulation of the Minister of Manpower and Transmigration Number 19 of 2012 concerning Conditions for Submitting Part of Work Implementation to Other Companies at PT. Semen Padang. Therefore, this research is exploratory. ${ }^{21}$ Since this research is an empirical (sociological) legal research, the main data used in this study are primary data, namely data obtained directly from the object of research through interviews and questionnaires.

This study uses purposive sampling technique, which is a technique to determine research samples with certain considerations. ${ }^{22}$ The purposive sampling technique is used because the research location that will be used as a reference in this study has been specifically selected and determined by the author, namely at PT. Semen Padang. The determination of PT. Semen Padang as a Research Location is because PT. Semen Padang is the largest company in Sumatra. PT.Semen Padang has 1,297 organic employees and 2,959 outsourcing workers. This company uses the largest outsourcing workforce, namely 2/3 of its employees are Outsourcing employees. Meanwhile, the number of companies providing labor services at PT Semen Padang is 58 companies. PT Semen Padang will be a role model or benchmark for the implementation of outsourcing. The large number of personnel and outsourcing companies does not rule out the possibility of causing several problems related to the implementation of laws and regulations related to manpower, both in operational and policy terms.

\section{Results and Discussion}

\section{A. Suitability of the Provision of Worker Services at PT. Semen Padang With Applicable Laws 1. Overview of Research Objects}

PT. (Limited Liability Company) Semen Padang is located in Indarung, Lubuk Kilangan District, Padang City, West Sumatra Province. PT. Semen Padang was founded on March 18, 1910 under the name NV.Nederlandsch Indische Portland Cement Maatschappij (NV NIPCM) which is the first cement factory in Indonesia. Then on July 5, 1958 the Company was nationalized by the Government of the Republic of Indonesia from the Government of the Netherlands. During this period, the Company underwent a revival process through rehabilitation and expansion of the Indarung I plant's capacity to 330,000 tons / year. Furthermore, the factory transformed the factory capacity development from wet process technology to dry process with the construction of the Indarung II, III and IV factories.

In 1995, the Government transferred its share ownership in PT Semen Padang to PT. Semen Gresik (Persero) Tbk together with the development of the Indarung V factory. Currently, the Company's shareholders are PT. Semen Indonesia (Persero) Tbk with a share ownership of $99.99 \%$ and the Big Family Cooperative of Semen Padang with a stake of $0.01 \%$. PT Semen Indonesia (Persero) Tbk itself is majority owned by the Government of the Republic of Indonesia at $51.01 \%$. The other $48.09 \%$ shareholders are owned by the public. PT. Semen Indonesia (Persero) Tbk. is a company whose shares are listed on the Indonesia Stock Exchange. Logo of PT. Semen Padang was first created in 1910, while it was named Nederlandsch Indische Portland Cement (Dutch Indies Cement Factory). The logo is only 3 years old because in 1913 a new logo was created, although a round shape with two circle lines and the words were preserved.

\section{Implementation of Provision of Worker Services at PT. Semen Padang With Applicable Laws}

PT. Semen Padang is the first cement company in Indonesia which has 4,256 employees. Of the total 4,256 employees, 1,297 were organic employees and 2,959 were outsourcing workers who came

\footnotetext{
${ }^{21}$ Amiruddin and H. Zainal Asikin, 2004, Introduction to Legal Research Methods, PT. RajaGrafindo Persada, Jakarta, p. $25-27$.

${ }^{22}$ Sugiyono, 2017, Quantitative Research Methods, Qualitative and R \& D, Alfabeta, Bandung p. 85.
} 
from the process of providing worker services (hereinafter referred to as Outsourcing Workers). This company uses the largest Outsourcing Worker, namely 69\% of its employees are Outsourcing Workers. Meanwhile, the number of companies providing labor services at PT. Semen Padang is a total of 73 (seventy three) companies providing labor services. Of the 73 labor supply companies, it can be categorized into three groups: First is the group of companies that are the largest suppliers of labor, namely the fewest over 30 workers and at most 1209. The largest number of supplier companies is 17 companies. The main largest company is PT. Pasoka Sumber Karya, which is also a subsidiary of PT. Semen Padang. The second group is companies that employ a workforce of 11 to 30 workers. There are 28 companies in this category. The third group is companies that employ a workforce of between 1 and 10 workers. There are 28 companies in this category.

There are several things that are mandatory requirements in the implementation of the Provision of Worker Services based on Law Number 13 of 2003 and Permenaker Number 19 of 2012, namely:

a. There is a work agreement between the worker and the worker service provider company.

This provision is regulated in Article 66 of Law No. 13 of 2003. Workers must have a work agreement with a company that provides worker services which can explain that there is a legal relationship between the worker and the company providing worker services. If the worker who does work at the employing company does not have an employment agreement with the company that provides the worker services, then the legal relationship status of the worker will be transferred to the employing company.

At PT. Semen Padang itself, all service provider companies have working agreements between workers and vendors that provide worker services. This is one of the administrative requirements that was first requested by PT. Semen Padang so that a company can become a service provider for workers. PT. Semen Padang and service providers must comply with this provision because if this requirement is not fulfilled by the worker service provider, legally the workers' responsibility will shift from the worker service provider to PT. Semen Padang.

From this work agreement, it can also be seen whether the worker service provider gives rights to workers in accordance with the cooperation agreement between PT. Semen Padang with worker service providers. Apart from complying with what is mandated by the law, it also aims to protect the rights of workers who are employed by service providers.

b. There is a Worker / Laborer Service Provision Agreement between the employing company and the worker service provider company

This provision is regulated in Article 19 of the Minister of Manpower Regulation No. 19 of 2012, which must at least contain the types of work to be performed by the company providing worker services, the transfer of protective measures, and the existence of a work relationship between workers and companies providing worker services in the form of PKWT or PKWTT. The spirit contained in this provision is to reinforce the rights and obligations between an employer and a worker service provider. In addition, this regulation provides protection for workers in the agreement between the employer and the worker service provider. PT. Semen Padang itself requires an agreement between PT. Semen Padang with its respective employer service providers. This is evident from the 73 companies that provide worker services in PT. Semen Padang, all of these companies have a cooperation agreement in terms of providing worker services at PT. Semen Padang. The cooperation agreement stipulates what rights and obligations are attached to PT. Semen Padang and companies providing worker services, the components of what costs will be paid by PT. Semen Padang to each company that provides worker services, and the most important thing is to regulate the mechanism for paying wages from the company providing worker

Legal Certainty for the Provision of Employee Services as the Intent of Protection of Labor Rights based on Labor Rights and Its Implementation in PT. Semen Padang 
services to each worker. The legal relationship that occurs in this case is actually only between PT. Semen Padang with a company that provides worker services, but in the framework of protecting workers' rights, PT. Semen Padang, through its cooperation agreement with each worker service provider, also regulates how to grant rights that must be given by the service provider company to its workers. This is a form of legal protection and concern for PT. Semen Padang to its workers even though in this case the worker is not an employee of PT. Semen Padang.

c. Employer service providers must be in the form of a Limited Liability Company (PT).

This provision is regulated in Article 24 of the Minister of Manpower Regulation No. 19 of 2012. Even though until now it is not known the background of the reasons for a worker service provider to be a PT legal entity, PT. Semen Padang has made it mandatory that every worker service provider who will cooperate with PT. Semen Padang is required to be legally incorporated as PT. This is no exception, where out of 73 companies providing worker services in PT. Semen Padang, all of these companies are legally incorporated as PT.

\section{d. Employment service providers must have an Operational Permit (SIO).}

This provision is regulated in Article 24 of the Minister of Manpower Regulation No. 19 of 2012. If a Vendor already has an SIO of Manpower Providers, administratively the vendor is deemed capable of running the manpower supply business. Therefore, these vendors can be included in the selection process to become a vendor for worker service providers at PT. Semen Padang. ${ }^{23}$

However, in practice, the facts show that from some vendors not all vendors have a Labor Provider SIO as required by Article 66 paragraph (3) of the Manpower Act. But the vendor in question already has sufficient management and financial capabilities to run a business as a provider of labor at PT. Semen Padang. Even so, these vendors who are generally domiciled in the vicinity of the company have received priority to be appointed as executing labor providers at PT. Semen Padang, with the consideration of siding with small companies and environmental development, as mandated in the Regulation of the Minister of BUMN No. 5/2008 jo No.15 / 2012 concerning General Guidelines for the Procurement of Goods and Services for BUMN. Of the 73 companies that provide worker services at PT. Semen Padang, there are 7 companies that do not have SIO.

One of the consequences that arise due to not fulfilling financial requirements is that many vendors do not have sufficient financial capacity, so that these vendors will only pay wages to their workers, after getting payment from PT. Semen Padang. This often arises from complaints from workers who have not received or are late in receiving their wages and this is certainly contrary to the principles of employment. If the vendor has sufficient financial capacity, these complaints should be prevented. Besides that, the vendor management ability to complete the billing administration aspects also affects the speed of payment for services by PT. Semen Padang, so that it will increasingly affect the financial condition of these vendors.

Based on the above matters, it can be concluded that:

a. The selection of a worker service provider provider greatly influences the management process of a worker service provider at PT. Semen Padang.

b. Environmental issues cause PT. Semen Padang must choose small-scale vendors who do not have strong financial capabilities to become service providers for workers.

\footnotetext{
${ }^{23}$ Interview with Mr. Iskandar S. Taqwa as Head of the PT Semen Padang Service Procurement Bureau for the 2013-2018 period on Monday 11 November 2019 at 09.00 WIB
} 
c. The process of issuing a Labor Provider SIO should consider the management and financial capabilities of the company, so that when the company gets a contract with another company as the owner of the job, it will not cause problems for its workforce.

d. Activities that can be carried out with the mechanism for providing worker services are limited to 5 jobs, namely:

i. Cleaning service businesses (cleaning service);

ii. The business of providing food for workers / laborers (catering);

iii. Security personnel business (security / security unit);

iv. Supporting service businesses in mining and petroleum; and

v. The business of providing transportation for workers / laborers.

This provision is regulated in Article 17 (3) of the Minister of Manpower Regulation Number 19 of 2012. Even though in practice there are still several work units at PT. Semen Padang which still uses worker service providers for jobs that are not regulated in Article 17 of the 2012 Minister of Manpower Regulation or even doing work that should be done by employees of PT. Semen Padang itself. For example, there are many workers who do administrative work, the same activities that are carried out by employees of each unit, and other jobs that are not in accordance with the Minister of Manpower Regulation Number 19 of 2012. Out of 73 companies providing worker services at PT. In Semen Padang, there are 12 companies that collaborate in providing worker services for jobs that are not required by Article 17 of the Minister of Manpower Regulation Number 19 of 2012. The above occurred because from a business perspective, PT. Semen Padang does have a policy to reduce labor costs, so that many workers from service provider vendors do work that should be done by employees of PT. Semen Padang, so it would be more profitable if the number of workers from the service provider did work similar to the work done by employees of PT. Semen Padang. In addition, this has not been avoided because regulations regarding workers' service providers already exist that regulate the types of work that can be submitted, but if this provision does not exist, there will not be any sanctions against this activity, so this practice is still ongoing. the name of the efficiency and profit of the company.

Based on the results of the interview, there are outsourcing workers who know and some do not know the concept of worker service providers as mentioned in Law Number 13 of 2003 and Regulation of the Minister of Manpower Number 19 of 2012. For workers who know that jobs can be submitted to service providers such as cleaning services, catering, drivers, mining services and security, the employee acknowledges that the work done (administration) is the work of the employees of PT. Semen Padang, however, the rights received are different because of their status as an Outsourcing Worker, however this work is still carried out for reasons rather than not having a job at all, it is better to become an Outsourcing Worker even though they have to carry out the work of an organic employee of PT. Semen Padang. For Outsourcing Workers who do not know the concept of worker service providers as stated in Law Number 13 of 2003 and Regulation of the Minister of Manpower Number 19 of 2012, after being given an understanding of these rules, it turns out that their opinions are the same as employees who have previously known the concept of Outsourcing. The expectations of these outsourcing workers are the same, namely that they have the desire to be appointed as organic employees of PT. Semen Padang because technically it has done the same job as the organic employees of PT. Semen Padang.

Based on the description of the above, of the 5 requirements required by Law Number 13 of 2003 and Regulation of the Minister of Manpower Number 19 of 2012, PT. Semen Padang only meets 2 requirements, namely the terms of the cooperation agreement between PT. Semen Padang with worker service providers and PT legal entity service provider requirements, for 3 other requirements, there must be a work agreement between workers and service providers, service providers must have an SIO and only 5 types of work are allowed by Permenaker No. 19 of 2012 is still not fulfilled. This shows that the implementation of the provision of worker services at PT. Semen Padang is partly still unable to provide legal certainty, especially in regulations related to manpower. The elements of legal certainty that are not

Legal Certainty for the Provision of Employee Services as the Intent of Protection of Labor Rights based on Labor Rights and Its Implementation in PT. Semen Padang 
fulfilled in the provision of worker services at PT. Semen Padang based on JM Otto's opinion is as follows :

1. Unavailability of clear, consistent and accessible rules issued by or recognized because of the (power) of the State. This can be seen in the absence of regulations on financial requirements for companies wishing to become workers' service providers. There should be financial provisions for service providers such as a good balance sheet, fresh money, and others because these companies will provide welfare to their workers. This can become a legal issue related to worker welfare such as payroll if this regulation is not established. Then there are no provisions regarding sanctions against companies that do not comply with the provisions of Article 17 Paragraph (3) of the Regulation of the Minister of Manpower and Transmigration Number 19 of 2012, in which jobs that can be submitted to workers' service providers must comply with the criteria in this Regulation. If a company provides a job to a service provider other than the criteria, then there should be a sanction that must be accepted by the company. This is necessary so that companies provide jobs to worker service providers that are limited to work that is not a core job (non-core business), core work cannot be given to worker service providers, so that jealousy of outsourcing employees to organic employees can be minimized because the work performed is not related between core business and non core business.

2. Whereas in principle the majority or the majority of citizens agree with the content and therefore adjust their behavior towards these rules. This happens as a manifestation of the absence of clear elements of rules so that in this case PT. Semen Padang did not adjust its actions to regulations related to manpower, including handing over jobs such as administration to service providers outside the provisions of the Minister of Manpower and Transmigration Regulation No. 19 of 2012.

\section{B. Fulfillment of Workers' Rights in Providing Worker Services at PT. Semen Padang}

The basic principles of Bentham's teaching on the purpose of law are that the law can guarantee happiness to individuals, then to many people. "The greatest happiness of the greatest number of people" (the greatest happiness of as many people as possible). This principle must be applied quantitatively, because the quality of pleasure is always the same. To realize individual and community happiness, the Manpower Act must achieve four objectives: (1) to provide subsistence (to provide a living); (2) to Provide abundance (to provide an abundance of food living); (3) to provide security (to provide protection); and (4) to attain equity (to achieve justice).

To be able to know firsthand the application of Bentham's teachings to the practice of providing employee services at PT. Semen Padang, we have to examine the actual conditions at PT. Semen Padang. For that, we need to do research on the condition of happiness (happiness) and also well-being.

Results of interviews with 18 (eighteen) Outsourcing Workers at PT. Semen Padang shows that the happiness level of outsourcing workers is quite good, except for the right to leave pay and the right to a salary. Meanwhile, the right to overtime, the right to rest, the right to annual leave, the right to sick leave and the right to health services statistically shows a satisfaction level of over $70 \%$. The right to salary shows the same rate of satisfaction and dissatisfaction. This is one form of the result of outsourcing workers doing work of the same type as the work done by organic employees of PT. Semen Padang. Of course, these workers are jealous of the wages they receive, while on the other hand, they only work for service providers. The right to leave money shows a $100 \%$ level of dissatisfaction because it is in the cooperation agreement between PT. Semen Padang and each company that provides worker services are not agreed to give this leave money and the company that provides worker services also does not give anything to its workers. This is also exacerbated by jealousy towards the organic employees of PT. Semen Padang, which received leave money from PT. Semen Padang. 
However, based on the results of an interview with Ka. HR Operations Unit, Mr. Irwan Prasetyo PT Semen Padang places the determination of the wage structure of Outsourcing Workers in the Outsourcing planning stage before the implementation of the Outsourcing procurement is carried out. This is done as one of the efforts of PT Semen Padang to provide legal protection to outsourcing workers. If we look at the theory of legal protection according to Philipus M.Hadjon, the activity of determining the wage structure is one of the means of preventive legal protection. The wage structure is determined as a reference in determining the budget (Owner Estimate) for service fees to be provided to companies providing worker / labor services. Provisions for the wage structure for outsourcing workers are stipulated in the Decree of the Board of Directors of PT Semen Padang No. 0000143 / HK.00.02 / SKD / 50003853/3000 / 12.2017 dated 21 December 2017 concerning Changes in the Value Structure of PT Semen Padang's Outsourcing Labor Contract (hereinafter referred to as PT.SP Outsourcing Wage Structure SKD). ${ }^{24}$

The purpose of making the PT.SP Outsourcing Wage Structure SKD is as a basis for carrying out the service procurement process and becomes a guide in the making and determination of the contract value for PT.Semen Padang Outsourcing Workers and as one of the assessment factors in monitoring the performance and practice of Good Corporate Governance (GCG) of the Outsourcing company (workers / labor service providers). ${ }^{25}$

Based on the SKD for PTSP Outsourcing Wage Structure, the wage structure for PT Semen Padang Outsourcing Workers is divided into several types, namely:

\section{1) Labor Wages}

Labor wages are money that must be received by outsourcing workers from companies that provide worker / labor services. ${ }^{26}$ This labor wage is divided into 3 components, namely : ${ }^{27}$

a) Basic Wage

Basic Wage is the basic salary paid to workers. ${ }^{28}$ The Basic Minimum Wage (UMP) which is the reference is the West Sumatra UMP. ${ }^{29}$

b) Fixed allowances

Permanent allowance is a payment to workers / laborers that is made regularly and is not linked to attendance or achievement of work performance. ${ }^{30}$ Fixed allowance consists of : ${ }^{31}$

i. The general allowance, which is given to outsourcing workers, is $8 \%$ of the West Sumatra UMP. $^{32}$

\footnotetext{
${ }^{24}$ Interview with Mr. M. Irwan Prasetyo, Head. HR Operational Unit of PT. Semen Padang on Monday 11 November 2019 at $14.00 \mathrm{WIB}$.

${ }^{25}$ Article 2 Decree of the Board of Directors of PT Semen Padang No. 0000143 / HK.00.02 / SKD / 50003853/3000 / 12.2017 dated 21 December 2017 concerning the Change in the Value Structure of PT Semen Padang's Outsourcing Labor Contract.

${ }^{26}$ Article 1 point 2 Decree of the Board of Directors of PT Semen Padang No. 0000143 / HK.00.02 / SKD / 50003853/3000 / 12.2017 dated 21 December 2017 concerning the Change in the Value Structure of PT Semen Padang's Outsourcing Labor Contract

${ }^{27}$ Article 3 Decree of the Board of Directors of PT Semen Padang No. 0000143 / HK.00.02 / SKD / 50003853/3000 / 12.2017 dated 21 December 2017 concerning the Change in the Value Structure of PT Semen Padang's Outsourcing Labor Contract

28 Article 1 point 4 Decree of the Board of Directors of PT Semen Padang No. 0000143 / HK.00.02 / SKD / 50003853/3000 / 12.2017 dated 21 December 2017 concerning the Change in the Value Structure of PT Semen Padang's Outsourcing Labor Contract

${ }^{29}$ Article 4 point 1 Decree of the Board of Directors of PT Semen Padang No. 0000143 / HK.00.02 / SKD / 50003853/3000 / 12.2017 dated 21 December 2017 concerning the Change in the Value Structure of PT Semen Padang's Outsourcing Labor Contract

${ }^{30}$ Article 1 point 5 Decree of the Board of Directors of PT Semen Padang No. 0000143 / HK.00.02 / SKD / 50003853/3000 / 12.2017 dated 21 December 2017 concerning the Change in the Value Structure of PT Semen Padang's Outsourcing Labor Contract

${ }^{31}$ Article 4 point 2 Decree of the Board of Directors of PT Semen Padang No. 0000143 / HK.00.02 / SKD / 50003853/3000 / 12.2017 dated 21 December 2017 concerning the Change in the Value Structure of PT Semen Padang's Outsourcing Labor Contract
} 
ii. Employment allowance, which is given to outsourcing workers of Rp. 5,000 (five thousand rupiah) per year of service. ${ }^{33}$

iii. Location allowance outside West Sumatra, which is given to outsourcing workers who are placed in areas with a higher UMP / UMR than the West Sumatra UMP. ${ }^{34}$

As in the basic wage section, the basic wage has been set at the UMP of West Sumatra, so that in the case of outsourcing workers placed in areas with a UMP / UMR that is higher than the UMP of West Sumatra, the difference in the UMP is with a minimum value of Rp. 300,000 (three hundred thousand Rupiah) will be an allowance for locations outside West Sumatra. Meanwhile, in the event that the outsourcing worker is placed in an area with a UMP / UMR lower than the UMP of West Sumatra, an allowance for locations outside West Sumatra of Rp. 300,000 (three hundred thousand Rupiah). ${ }^{35}$

iv. Position Allowance, which is given to outsourcing workers according to their respective position levels. ${ }^{36}$

c) Non-Permanent Allowances

Non-permanent allowance is a payment to a worker / laborer that is made irregularly and is linked to non-permanent variables such as attendance or achievement of work performance. ${ }^{37}$ Variable benefits consist of : ${ }^{38}$

a) Attendance allowance, which is given to outsourcing workers in accordance with the attendance level of the outsourcing workforce. In the event that the outsourcing worker arrives late in accordance with the set working hours, the attendance allowance will be deducted according to the presentation of the delay. ${ }^{39}$

b) Support shifts, which is given to outsourcing workers who work in shifts. ${ }^{40}$

c) Risk Allowance, which is given to outsourcing workers who are placed in certain highrisk areas. ${ }^{41}$

\footnotetext{
32 Article 4 point 2 letter a Decree of the Board of Directors of PT Semen Padang No. 0000143 / HK.00.02 / SKD / 50003853/3000 / 12.2017 dated 21 December 2017 concerning the Change in the Value Structure of PT Semen Padang's Outsourcing Labor Contract

${ }^{33}$ Article 4 point 2 letter b Decree of the Board of Directors of PT Semen Padang No. 0000143 / HK.00.02 / SKD / $50003853 / 3000 / 12.2017$ dated 21 December 2017 concerning the Change in the Value Structure of PT Semen Padang's Outsourcing Labor Contract

${ }^{34}$ Article 1 point 13 Decree of the Board of Directors of PT Semen Padang No. 0000143 / HK.00.02 / SKD / 50003853/3000 / 12.2017 dated 21 December 2017 concerning the Change in the Value Structure of PT Semen Padang's Outsourcing Labor Contract

35 Article 4 point 2 letter c Decree of the Board of Directors of PT Semen Padang No. 0000143 / HK.00.02 / SKD / $50003853 / 3000 / 12.2017$ dated 21 December 2017 concerning the Change in the Value Structure of PT Semen Padang's Outsourcing Labor Contract

36 Article 4 point 2 letter d Decree of the Board of Directors of PT Semen Padang No. 0000143 / HK.00.02 / SKD / 50003853/3000 / 12.2017 dated 21 December 2017 concerning the Change in the Value Structure of PT Semen Padang's Outsourcing Labor Contract

37 Article 1 point 6 letter d Decree of the Board of Directors of PT Semen Padang No. 0000143 / HK.00.02 / SKD / 50003853/3000 / 12.2017 dated 21 December 2017 concerning the Change in the Value Structure of PT Semen Padang's Outsourcing Labor Contract

38 Article 4 point 3 letter d Decree of the Board of Directors of PT Semen Padang No. 0000143 / HK.00.02 / SKD / 50003853/3000 / 12.2017 dated 21 December 2017 concerning the Change in the Value Structure of PT Semen Padang's Outsourcing Labor Contract

${ }^{39}$ Interview with Mr. Iskandar S. Taqwa as Head of the PT Semen Padang Service Procurement Bureau for the 2013-2018 period on Monday 11 November 2019 at 09.00 WIB

${ }^{40}$ Article 1 point 16 Decree of the Board of Directors of PT Semen Padang No. 0000143 / HK.00.02 / SKD / 50003853/3000 /

12.2017 dated 21 December 2017 concerning the Change in the Value Structure of PT Semen Padang's Outsourcing Labor Contract

${ }^{41}$ Article 1 point 17 Decree of the Board of Directors of PT Semen Padang No. 0000143 / HK.00.02 / SKD / 50003853/3000 / 12.2017 dated 21 December 2017 concerning the Change in the Value Structure of PT Semen Padang's Outsourcing Labor Contract
} 
d) Adjustment Allowance, which is given to outsourcing workers due to changes in the wage structure whose value is adjusted periodically. ${ }^{42}$

\section{2) Normative Wages}

Normative Wages are money that an employer pays to a company providing services for workers / labor in the context of fulfilling the normative rights of workers, in accordance with the prevailing laws and regulations. ${ }^{43}$ In principle, this normative wage is the amount of obligation that must be issued by a labor service provider company to fulfill its obligations under laws and regulations where the money is not given directly to outsourcing workers, such as the payment of the Social Security Administering Body (BPJS). The purpose of this normative wage component is for service providers for workers / laborers to carry out their obligations to outsourcing workers in accordance with statutory regulations. ${ }^{44}$ Normative wages consist of $:^{45}$

a) Payment of BPJS (Social Security Administering Bodies) consisting of BPJS Kesehatan and BPJS Ketenagakerjaan. The amount is in accordance with that stipulated in the statutory regulations.

b) Religious allowances, which are workers' rights at least once a year before the religious holidays of each worker.

c) Severance pay, which is money that will be given by the company to workers who have experienced termination of employment (PHK).

d) Other optional Normative Wages in the form of compensation money, leave compensation money, reward money and medical check up fees.

\section{3) Natura's Wages}

Natura's Wages are money paid by employers to companies providing worker / labor services, which are given to workers in the form of work equipment (work clothes / shoes, safety equipment / equipment, etc.) as needed. ${ }^{46}$ Similar to normative wages, the amount of money in kind is not received directly by outsourcing workers but is received in the form of tools or work equipment. The purpose of this in-kind wage to be a component of the Outsourcing wage is so that the Outsourcing worker gets all work equipment and equipment so that the work can be carried out without any reason for lack of equipment or work equipment.

\section{4) Entrepreneur Fee}

Entrepreneur Fees are service fees paid by the employing company (PT. Semen Padang) to workers / labor service providers. ${ }^{47}$ This entrepreneur fee is purely aimed at companies providing worker / labor services only. The amount of the entrepreneur's fee is a maximum of $10 \%$ of the total basic wage, normative wages and in-kind wages. The purpose of Entrepreneur Fees are included in the component of outsourcing wages so that the service provider company workers / laborers will not deduct the wages that will be received by outsourcing workers. ${ }^{48}$

\footnotetext{
${ }^{42}$ Article 1 point 18 Decree of the Board of Directors of PT Semen Padang No. 0000143 / HK.00.02 / SKD / 50003853/3000 / 12.2017 dated 21 December 2017 concerning the Change in the Value Structure of PT Semen Padang's Outsourcing Labor Contract

${ }^{43}$ Article 1 point 7 Decree of the Board of Directors of PT Semen Padang No. 0000143 / HK.00.02 / SKD / 50003853/3000 / 12.2017 dated 21 December 2017 concerning Changes in the Value Structure of PT Semen Padang's Outsourcing Labor Contract ${ }^{44}$ Interview with Mr. Iskandar S. Taqwa as Head of the PT Semen Padang Service Procurement Bureau for the 2013-2018 period on Monday 11 November 2019 at 09.00 WIB

${ }^{45}$ Article 5 Decree of the Board of Directors of PT Semen Padang No. 0000143 / HK.00.02 / SKD / 50003853/3000 / 12.2017 dated 21 December 2017 concerning Changes in the Value Structure of PT Semen Padang's Outsourcing Labor Contract ${ }^{46}$ Article 1 point 8 Decree of the Board of Directors of PT Semen Padang No. 0000143 / HK.00.02 / SKD / 50003853/3000 / 12.2017 dated 21 December 2017 concerning Changes in the Value Structure of PT Semen Padang's Outsourcing Labor Contract ${ }^{47}$ Article 11 point 9 Decree of the Board of Directors of PT Semen Padang No. 0000143 / HK.00.02 / SKD / 50003853/3000 / 12.2017 dated 21 December 2017 concerning Changes in the Value Structure of PT Semen Padang's Outsourcing Labor Contract ${ }^{48}$ Interview with Mr. Iskandar S. Taqwa as Head of the PT Semen Padang Service Procurement Bureau for the 2013-2018 period on Monday 11 November 2019 at 09.00 WIB
} 


\section{5) Add Jobs}

Additional work is an additional wage given to outsourcing workers outside normal working hours (overtime) or due to an official trip. ${ }^{49}$ Overtime wages are mandatory in the Outsourcing wage component because they are required by statutory regulations. Provisions regarding the amount of overtime refer to the Decree of the Minister of Manpower and Transmigration Number 102 / MEN / VI / 2004 concerning Overtime Work and Overtime Wages. Based on the SKD Outsourcing PTSP Wage Structure, the calculation of overtime is divided into two, namely $:^{50}$

a) Overtime pay for outsourcing workers, the amount of which is (75\% x labor wages) / 173 which is the same as stipulated in the ministerial decree regarding overtime wages above.

b) Official travel, the amount of which is regulated separately and will be stated in the agreement.

Based on the five components of the wage structure prepared by PT. Semen Padang, almost all of them have a fixed multiplier variable (number) in which the company providing worker / labor services cannot request additional or PT. Semen Padang asked for a reduction, except for the components of the entrepreneur's fee, both the entrepreneur's fee as a whole and the entrepreneur's fee for overtime. This entrepreneur fee component will be the bargaining chip between PT. Semen Padang as an employer with a company providing worker / labor services.

Other forms of legal protection provided by PT. Semen Padang to company workers who provide worker services is by making a cooperation agreement between PT. Semen Padang and all companies providing worker services. Even though PT. Semen Padang does not have a legal relationship with company workers who provide service workers, but in the interest of protecting the fulfillment of these workers' rights, PT. Semen Padang requires in the cooperation agreement the following :

1. The requirements of each company providing worker services must have a work agreement with its workers;

2. Workers must be provided with protection in the form of BPJS Kesehatan and BPJS Ketenagakerjaan;

3. Employer service providers must pay wages to their workers in accordance with the prevailing wage structure at PT. Semen Padang, in this case based on the Decree of the Board of Directors of PT Semen Padang No. 0000143 / HK.00.02 / SKD / 50003853/3000 / 12.2017 dated 21 December 2017 concerning Changes in the Value Structure of PT Semen Padang's Outsourcing Labor Contract (see table 9);

4. Employer service providers must register a work agreement with the Manpower Office;

5. Employer service providers must provide personal protective equipment (PPE) to each of its workers when working in a high-risk workplace;

6. Ensure that service providers always pay salaries to workers on time.

Cooperation agreement between PT. Semen Padang with all service providers is a legal instrument that binds PT. Semen Padang with worker service providers because based on the principle of Pacta Sunt Servanda which is regulated in Article 1338 of the Civil Code, the cooperation agreement will be legally binding for the parties who make it. PT. Semen Padang and workers 'service providers must comply with all the provisions contained in the agreement, including provisions protecting workers' rights. If one of the parties does not comply with this agreement, then that party can be said to be in default and does not comply with the provisions of laws and regulations related to employment. In addition to providing legal protection through a cooperation agreement, PT. Semen Padang is also

\footnotetext{
${ }^{49}$ Article 1 point 10 Decree of the Board of Directors of PT Semen Padang No. 0000143 / HK.00.02 / SKD / 50003853/3000 / 12.2017 dated 21 December 2017 concerning Changes in the Value Structure of PT Semen Padang's Outsourcing Labor Contract ${ }^{50}$ Article 8 Decree of the Board of Directors of PT Semen Padang No. 0000143 / HK.00.02 / SKD / 50003853/3000 / 12.2017 dated 21 December 2017 concerning Changes in the Value Structure of PT Semen Padang's Outsourcing Labor Contract
} 
proactive in being able to cooperate with the local Manpower Office if it is found that the company providing worker services has violated the provisions of the cooperation agreement and / or has violated the prevailing laws and regulations.

Forms of legal protection apart from requirements based on laws and regulations related to manpower, requirements from PT. Semen Padang and the implementation of the cooperation agreement with due observance of the laws and regulations related to manpower, there are other things that can be done by PT. Semen Padang to protect the rights of its outsourcing workers, namely by requiring that the agreement between the worker service provider and the worker, must at least be legalized before a notary. If the worker service provider makes an authentic deed then this is even better.

The problems that often arise in the provision of worker services at PT. Semen Padang is that some workers do not know that they have signed a work agreement with a worker service provider and that there is a work agreement between a worker service provider and a worker that is not in accordance with laws and regulations related to manpower. Regarding these 2 problems, based on the authority possessed by the Notary, PT. Semen Padang may require that a work agreement between a worker service provider and a worker must at least be legalized before a notary. This is expected to prevent workers from not knowing that workers have or have not signed a work agreement. This also prevents the forgery of work agreement documents. On the other hand, PT. Semen Padang may also require worker service providers that workers and workers are required to have an agreement in the form of an authentic deed made before a notary with the consequence of proving that the work agreement will be more perfect.

Of course, the above requirements have the consequence that there will be additional costs in legalizing or making authentic deeds of work agreements. If many service providers object, then PT. Semen Padang can cover this cost through its outsourcing wage structure. At least PT. Semen Padang requires legalization because legalization will not incur costs as big as making an authentic deed and besides that, as previously stated that PT. Semen Padang will benefit in the form of preventing workers' ignorance that workers have signed or not signed a work agreement and preventing falsification of work agreement documents.

Based on the foregoing, Bentham's teaching on the purpose of law is that law can guarantee happiness to individuals, then to the masses. "The greatest happiness of the greatest number of people" (the greatest happiness of as many people) regarding the fulfillment of the rights of outsourcing workers has been fulfilled. The objectives in fulfilling these are as follows:

1. To provide subsistence. This can be proven by PT. Semen Padang to service providers with the amount above the West Sumatra UMP;

2. Providing abundance of living. This can be proven by the number of wage component variables that PT. Semen Padang to service providers for workers;

3. Provide protection. This can be proven by the presence of a component of BPJS Kesehatan and BPJS Ketenagakerjaan in the wage component provided by PT. Semen Padang to service providers.

The element of preventive legal protection according to Philipus M Hadjon for workers from worker service providers has also been fulfilled by the enactment of the Decree of the Directors of PT Semen Padang No. 0000143 / HK.00.02 / SKD / 50003853/3000 / 12.2017 dated 21 December 2017 concerning the Change in the Value Structure of the Outsourcing Labor Contract of PT Semen Padang. One of the objectives of this Decree of the Board of Directors is to ensure that workers from companies providing employee services receive their rights in accordance with the prevailing laws and regulations. This can fulfill the element of preventing (prevent) disputes between workers and service providers and / or PT. Semen Padang, due to this Decree of the Board of Directors, describes in detail the rights received by Outsourcing Workers. 


\section{Negative and Positive Consequences of the Application of the Provision of Worker Services on Workers' Rights at PT. Semen Padang}

Based on interviews that have been conducted at PT. Semen Padang, the consequences of the implementation of the Provision of Worker Services on the rights of workers at PT. Semen Padang has negative consequences and positive consequences.

\section{Negative consequences}

Outsourcing workers at PT. Semen Padang has very close work coordination with all organic employees of PT. Semen Padang. In addition, if viewed from the workplace, the workplace between outsourcing workers and organic employees of PT. Semen Padang is also close to each other. What distinguishes between outsourcing workers and organic employees of PT. Semen Padang is the type of work performed, the uniform used, and the differences in workers' rights. Although between outsourcing workers and organic employees of PT. Semen Padang has differences, but because of its proximity to the workplace and work coordination, there is a sense of jealousy among the outsourcing workers towards the organic employees of PT. Semen Padang. In terms of the type of work, the work carried out is not too much different, the coordination of work is very close with the Organic Employees of PT. Semen Padang, however, because there are differences in the rights received even though the rights that have been received are in accordance with the laws and regulations related to employment it triggers jealousy and makes Outsourcing Workers also want to become organic employees of PT. Semen Padang.

Based on the Job Satisfaction Theory put forward by Robbins, this can happen because workers basically will always compare themselves with the surrounding work environment, and compare what they do with what they receive. If this situation continues at PT. Semen Padang, so this is certainly not good for PT. Semen Padang because based on the opinion of Kreitner and Kinicki, the job satisfaction of workers will be related to many things, one of which is the work performance of the workers themselves. The impact that may arise on these matters is the performance of PT. Semen Padang will be disrupted due to the low performance of outsourcing workers.

If this jealousy continues, then this is certainly not in line with the spirit of Law Number 13 of 2003 concerning Manpower where there is no discrimination against workers. Meanwhile, in its implementation, it seems as if the worker service provider can cause discrimination between the Outsourcing Worker and the Organic employee of PT. Semen Padang. If the concept of service providers is still implemented, then the closeness between the Outsourcing Worker and the Organic employee of PT. Semen Padang should be terminated by forming regulations regarding workplaces that are not close together and have absolutely no coordination.

\section{Positive consequences}

PT. Semen Padang is demanded by its shareholders to generate large amounts of profit. This demand made the management of PT. Semen Padang has to do various ways to create maximum income and spend as economically as possible. Large income will be obtained from the sale of cement, noncement, and other income that can make the income balance of PT. Semen Padang is getting taller. Meanwhile, to save on expenses, this is done by reducing the cost of cement production, where one of the components is labor costs. The cost of labor itself consists of the cost of organic labor and the cost of outsourcing workers, both through contracting jobs and providing worker services.

Labor costs can be reduced in one way through the provision of worker services. PT. Semen Padang spends quite a lot of money on its organic workforce. If PT. Semen Padang must employ all of its workers with the status of organic employees, so this will cause even greater costs because organic

Legal Certainty for the Provision of Employee Services as the Intent of Protection of Labor Rights based on Labor Rights and Its Implementation in PT. Semen Padang 
employees have more rights than outsourcing workers. There are 4 components that are not accepted by outsourcing workers, namely:

a. Yearly bonus;

b. Medical Check Up;

c. Health insurance outside BPJS;

d. Annual leave pay and large leave.

Apart from the above income components, there is also a difference in basic wages between organic employees and outsourcing workers. Outsourcing worker basic wage is equal to the Provincial Minimum Wage (UMP), while the organic employee basic wage of PT. Semen Padang is above the UMP.

With a total of 1,297 organic employees and 2,959 outsourcing workers, there is a potential for a much bigger expense if 2,959 outsourcing workers must be made organic employees. To reduce labor costs, PT. Semen Padang always makes policies related to the empowerment of Outsourcing Workers, both from contracting jobs and providing worker services. If you look at the regulations related to manpower, the concept of worker service providers is not against the regulations, but in the implementation of worker service providers, the existing rules are still not able to regulate its implementation, especially at PT. Semen Padang.

\section{Conclusion}

1. The provision of employee services at PT. Semen Padang still does not comply with the applicable law. On the one hand, PT. Semen Padang has implemented the provisions of Article 66 paragraph (3) of the Manpower Act. PT. Semen Padang has set one of the most basic requirements if a vendor wishes to become a Worker Service Provider. These conditions are that the vendor must have an Operational Permit (SIO) for the Worker Provider issued by the West Sumatra Province Manpower Office (Disnaker). PT Semen Padang has also complied with the provisions of Article 17 Paragraph (3) of the Regulation of the Minister of Manpower and Transmigration No. 19/2012, jobs that can be submitted to labor service providers are support services that are not directly related to the production process, including: (a) cleaning service businesses; (b) The business of providing food for workers / laborers (catering); (c) Security personnel business (security / security unit); (d) Support services in mining and petroleum; and (e) Efforts to provide transportation for workers / laborers. On the other hand, PT. Semen Padang still uses worker service providers for jobs that are not regulated in Article 17 of the 2012 Minister of Manpower Regulation or even doing work that should be done by employees of PT Semen Padang itself. For example, there are many workers who carry out administrative work, the same activities carried out by employees of each unit, and other jobs that are not in accordance with the Minister of Manpower Regulation Number 19 of 2012. This is a form of not creating legal certainty for the provision of worker services.

2. Fulfillment of the rights of outsourcing workers at PT Semen Padang is carried out quite well, where this can be proven by PT Semen Padang providing legal protection to outsourcing workers through the Decree of the Board of Directors of PT Semen Padang No. 0000143 / HK.00.02 / SKD / 50003853/3000 / 12.2017 dated 21 December 2017 concerning the Change in the Value Structure of PT Semen Padang's Outsourcing Labor Contract, which has determined and paid to Outsourcing workers in the form of Labor Wages consisting of Basic Wages, Fixed Allowances and Variable Benefits; Normative Wages; Natura's Wages; Entrepreneur Fee; and additional jobs. The happiness level of agency workers is above $70 \%$. 
3. Implementation of Provision of Worker Services at PT. Semen Padang has negative consequences and positive consequences. The negative consequence is the high level of jealousy of the outsourcing workers towards organic workers, both in terms of the type of work performed, the uniforms worn, and differences in workers' rights. This is not in line with the spirit of Law No. 13 of 2003 concerning Manpower where there is no discrimination against workers. Meanwhile, in its implementation, it seems as if the worker service provider can cause discrimination between the Outsourcing Worker and the Organic employee of PT. Semen Padang. One of the positive consequences of employing outsourcing workers, labor costs can be reduced in one way through the provision of worker services. Consequently, PT. Semen Padang is able to pay the annual bonus; Medical Check Up; Health insurance outside BPJS; Annual leave and leave pay for organic workers. The concept of worker service provider is not against the regulations, but in the implementation of worker service providers, the existing regulations have not been able to regulate its implementation, especially at PT. Semen Padang.

\section{Suggestion}

Based on the conclusions stated above, there are 3 suggestions that can be proposed as corrections for the common good.

1. It is recommended that the House of Representatives of the Republic of Indonesia and the Government of Indonesia revise Law no. 13 of 2003 concerning articles that are still unable to provide legal certainty, causing a mismatch in the implementation of the provision of worker services at PT. Semen Padang, including Article 64 and Article 66. It is also recommended that the Ministry of Manpower and Transmigration be able to revise the Regulation of the Minister of Manpower and Transmigration No. 19 of 2012 in order to contain sanctions for companies that are still practicing worker service providers apart from the 5 criteria required in the regulation.

2. It is recommended that the Directors and Commissioners of PT Semen Padang continue to supervise the Decree of the Directors of PT Semen Padang No. 0000143 / HK.00.02 / SKD / 50003853/3000 / 12.2017 dated December 21, 2017 concerning Changes in the Structure of PT Semen Padang's Outsourcing Labor Contract Value so that the fulfillment of workers' rights in the provision of worker services at PT. Semen Padang can operate in accordance with the prevailing laws and regulations. Directors of PT. Semen Padang is also advised to add requirements to Worker Service Providers that Worker Service Providers must carry out legalization before a Notary regarding the Work Agreement between Worker Service Providers and their workers.

3. It is recommended that the Directors and Commissioners of PT Semen Padang address the differences in welfare between organic employees and outsourcing workers, which can lead to social jealousy.

\section{Thank-You Note}

The author would like to thank all those who supported the writing of this article and give the highest appreciation to the Faculty of Law, Andalas University, Padang, Indonesia. 


\section{Bibliography}

Book

Amiruddin and H. Zainal Asikin, Introduction to Legal Research Methods, PT. Raja Grafindo Persada, Jakarta, 2004.

Adrian Sutedi, Labor Law, Sinar Grafika, Jakarta, 2011.

Evi Rosmanasari, Implementation of Legal Protection for Outsourcing Workers of PT. Indah Karya Nuansa Indonesia (PT. INKANINDO) at PT. Pertamina (Persero) UP-VI Balongan, Thesis, Diponegoro University, 2006.

FX Djumiadji, Contracting Agreement, Bina Aksara Publisher, Jakarta, 1987.

Khairani, Legal Certainty of the Rights of Outsourcing Workers in terms of the concept of a working relationship between workers and employers, PT. Raja Grafindo Persada, Jakarta, 2016.

Then Husni, Indonesian Manpower Law, Revised Edition, Rajawali Pers, Jakarta, 2015.

Muhamad Azhar, Manpower Law Textbook, Indonesian Police Academy, Semarang, 2010.

Sehat Damanik, Outsourcing \& Work Agreement According to Law Number 13 Year 2003 concerning Employment, DSS Publishing, Jakarta, 2008.

Soetandyo Wignyosubroto, Law, Paradigm, Methods and the Dynamics of the Problem, Elsham, Jakarta, 2002.

Sugiyono, Quantitative Research Methods, Qualitative and R \& D, Alfabeta, Bandung, 2017.

\section{Constitution}

"Law Number 22 Year 1957 concerning Settlement of Hunting Disputes," State Gazette, Number 22 Year 1957.

"Law Number 12 of the Year concerning Termination of Employment in Private Companies," State Gazette Number 12 of 1964, Supplement to the State Gazette Number 2686.

"Law Number 21 of 2000 concerning Trade Unions / Labor Unions," State Gazette No. 131 of 2000, Supplement to the State Gazette Number 3989.

"Law Number 13 of 2003 concerning Manpower," State Gazette No. 39 of 2003, Supplement to the State Gazette Number 4279.

\section{Journal}

Abd. Munir, "Structural Victimization of Workers Through the Outsourcing System (Case Study: Outsourcing Workers of PT. (X) employed at PT. (Y) in Serang Regency)," Indonesian Journal of Criminology, Volume 9 Number 1, 2013.

Gotra Lidya Puspita and Mochamad Affandi, "Analysis of the Distribution of Labor by Outsourcing Companies in Airlines Companies (Case Study at PT. Mandala Airlines," JIEP, Volume 15 Number 2 November 2015, 2015.

Khairani, "Position of Outsourcing After the Decision of the Constitutional Court Number 27 / PUU-IX / 2011", Journal of the Constitution Volume 11, 2014.

Khairani, "Realizing Legal Protection for Outsourcing Workers through Synchronization of Labor Regulations, Journal of Dynamics Faculty of Law, Jendral Soedirman University Volume 15 Number 3, 2015.

Sonhaji, "Legal Aspects of Work Relations through the Outsourcing Mechanism Based on Law no. 13 of 2003 concerning Manpower, "Magazine of Legal Issues, Volume 36 Number 2, 2007.

Mukhammad Riza Anugra Vidi and M. Arif Affandi, "Labor Union Resistance Movement for Outsourcing Systems and Wage Systems at PT JAPFA Comfeed Sidoardjo," Paradigma, Volume 03 Number 1, 2015. 


\section{Internet}

Ariswan, Regarding Outsourcing Personnel, http://malangnet.wordpress.com, (Accessed on January 26, 2015).

\section{Decision}

Decree of the Board of Directors of PT Semen Padang No. 0000143 / HK.00.02 / SKD / 50003853/3000 / 12.2017 dated December 21, 2017 concerning Changes in the Value Structure of the Outsourcing Labor Contract of PT.Semen Padang.

\section{Copyrights}

Copyright for this article is retained by the author(s), with first publication rights granted to the journal.

This is an open-access article distributed under the terms and conditions of the Creative Commons Attribution license (http://creativecommons.org/licenses/by/4.0/). 